\title{
At-Taqaddum
}

Vol. 10 No. 2 (2018) pp 109-142

DOI: http://dx.doi.org/10.21580/at.v10i2.2985

\section{PENGARUH JENIS PEKERJAAN DAN TINGKAT \\ PENDIDIKAN TERHADAP PERCERAIAN \\ DI PENGADILAN AGAMA SEMARANG \\ TAHUN 2015}

Rokhmadi

Universitas Islam Negeri Walisongo Semarang

Email: rokhmadi@walisongo.ac.id

\begin{abstract}
This research tries to know the influence of work type and level of education to divorce in Religious Court of Semarang Year 2015. This type of research is field research that is quantitative and qualitative in nature. The quantitative approach, which is to find out the relationship and differences in the variables influence the type of work, and the level of education to the occurrence of divorce in the Semarang Religious Court in 2015. While the qualitative data approach is used as an analysis material from quantitative results. The result of first bypothesis in this research is accepted that society having background of work type non-state civil apparatus will tend to easier to divorce, while people with a background of the type of work as state civil apparatus servants tend to be better able to control themselves from divorce, because the variables not in the equation score 6.512 with a significance level of 0.011 smaller than $0.05 \quad(0.011<0.05)$. The second bypothesis is accepted that people with with elementary and secondary will tend to be easier to divorce, while those with higher education will tend to be better able to control themselves from divorce because the variables not in the equation score of 5,738 with significance level of 0.017 less than 0.05 (0.017<0.05); and the third bypothesis is also accepted that people with background of non-state civil apparatus and elementary and secondary will tend to be easier to divorce, whereas people with background types of work as State civil apparatus and higher education will tend to be more able to control themselves from divorce, because the variables not in the equation scores are 10.861 with a significance level of 0.004 smaller than $0.05(0.004<0.05)$.
\end{abstract}

Keywords: Job type, education level, divorce

Rokhmadi, Pengaruh Jenis Pekerjaan... 


\begin{abstract}
Abstrak
Penelitian ini berusaha untuk mengetahui pengaruh jenis pekerjaan dan tingkat pendidikan terhadap perceraian di Pengadilan Agama Semarang Tahun 2015. Jenis penelitian ini adalah penelitian lapangan (field research) yang bersifat kuantitatif dan kualitatif. Pendekatan kuantitatif, yaitu untuk mengetahui hubungan dan perbedaan pada variabel pengaruh jenis pekerjaan, dan tingkat pendidikan terhadap terjadinya perceraian di Pengadilan Agama Semarang Tahun 2015. Sedangkan pendekatan data kualitatif digunakan sebagai bahan analisis dari hasil kuantitatif. Hasil hipotesis pertama dalam penelitian ini adalah diterima bahwa masyarakat yang memiliki latar-belakang jenis pekerjaan Non-ASN akan cenderung lebih mudah melakukan perceraian, sedangkan masyarakat dengan latar-belakang jenis pekerjaan sebagai ASN cenderung akan lebih mampu mengendalikan diri dari melakukan perceraian, karena variabel tidak dalam persamaan (variables not in the equation) skornya 6,512 dengan taraf signifikansi 0,011 lebih kecil dari $0,05(0,011<0,05)$. Hipotesis kedua diterima bahwa masyarakat yang tingkat pendidikan dasar dan menengah akan cenderung lebih mudah melakukan perceraian, sedangkan masyarakat yang tingkat pendidikan tinggi akan cenderung lebih mampu mengendalikan diri dari melakukan perceraian, karena variabel tidak dalam persamaan (variables not in the equation) skornya 5,738 dengan taraf signifikansi 0,017 lebih kecil dari 0,05 $(0,017<0,05)$; dan Hipotesis ketiga juga diterima bahwa masyarakat yang memiliki latarbelakang jenis pekerjaan Non-ASN dan tingkat pendidikan dasar dan menengah akan cenderung lebih mudah melakukan perceraian, sedangkan masyarakat dengan latar-belakang jenis pekerjaan sebagai ASN dan tingkat pendidikan tinggi akan cenderung lebih mampu mengendalikan diri dari melakukan perceraian, karena variabel tidak dalam persamaan (variables not in the equation) skornya 10,861 dengan taraf signifikansi 0,004 lebih kecil dari 0,05 $(0,004<0,05)$.
\end{abstract}

Keywords: Jenis pekerjaan, tingkat pendidikan, perceraian 


\section{Pendahuluan}

Tingkat perceraian di Kota Semarang, sebagai ibu kota Jawa Tengah, tergolong tinggi selama kurun waktu tahun 2015-2016. Dari data Pengadilan Agama Kelas 1-A Semarang, pada tahun 2015, jumlah perceraian di Ibu Kota Provinsi Jawa Tengah itu mencapai 3.119 kasus dan semuanya telah diputuskan dalam persidangan. Dari data 3.119 kasus tersebut hampir 70\% lebih atau sebanyak 2.197 kasus perceraian diajukan oleh pihak perempuan (isteri), sedangkan sisanya sebanyak 922 kasus adalah cerai talak atau cerai yang diajukan dari pihak laki-laki (suami). Dari data tersebut juga tercatat, jika tingkat perceraian tertinggi terjadi pada bulan Agustus 2015 dengan jumlah kasus cerai gugat oleh pihak isteri sebanyak 235 kasus dan kasus cerai talak oleh pihak suami sebanyaak 95 kasus saja. ${ }^{1}$

Kebanyakan perempuan yang mengajukan gugatan cerai disebabkan berbagai alasan. Salah satunya, karena mereka menganggap suami tidak bertanggungjawab dalam memberikan nafkah. Selain itu, ada juga yang mengajukan cerai karena keberadaan pihak ketiga (selingkuh) hingga perbedaan pendapat," terang Humas Pengadilan Agama Kelas 1-A Semarang, M. Sukri, saat dijumpai wartawan, Rabu (27/1/2016). Selain alasan-alasan itu, Sukri juga mengaku bahwa perceraian juga disebabkan adanya kekerasan dalam rumah tangga (KDRT). KDRT inilah yang

\footnotetext{
1 Samsul, "Kasus perceraian tergolong tinggi, 70\% perceraian di Semarang diajukan perempuan," Semarang Pos, 19 Maret 2016, http://www.semarangpos.com/2016/01/28/kasus-perceraian-tergolong-tinggi-70perceraian-di-semarang-diajukan-perempuan-685408. html.
}

Rokhmadi, Pengaruh Jenis Pekerjaan dan ... 
menjadi salah satu faktor pemicu para perempuan mengajukan cerai kepada suaminya. ${ }^{2}$

Meski perceraian di Kota Semarang cukup tinggi, pihak Pengadilan Agama tetap berusaha memberikan mediasi terlebih dahulu kepada pihak pengugat maupun tergugat sebelum menggelar persidangan. Meski demikian, Sukri mengaku tidak banyak di antara mediasi yang dilakukan tersebut berbuah manis dan berujung damai antara pihak suami dan isteri. $^{3}$

Ini berarti bahwa angka perceraian di Kota Semarang masih tergolong cukup tinggi. Dalam sebulan rata-rata 200-290 pasangan suamiisteri bercerai. Sebagian besar kasus-kasus tersebut didominasi gugatan dari pihak isteri.

Tren perceraian di Kota Semarang selama lima tahun terakhir menunjukkan grafik peningkatan. Namun jumlah kasus perceraian tertinggi terjadi pada tahun 2013 yang mencapai 3.477 kasus, terdiri atas 925 kasus dari suami melakukan cerai-talak dan 2.552 kasus cerai-gugat dari isteri. Itu artinya rata-rata ada 290 pasangan suami-isteri yang bercerai setiap bulannya, atau dalam sehari hampir 10 pasangan bercerai. ${ }^{4}$

Berturut-turut selama lima tahun mulai tahun 2010 sebanyak 2.441 kasus perceraian, tahun 2011 sebanyak 2.662 kasus, tahun 2012 sebanyak 2.816 kasus, tahun 2013 sebanyak 3.477 kasus, tahun 2014 sebanyak 3.116

2 Samsul, "Kasus perceraian tergolong tinggi, 70\% perceraian di Semarang diajukan perempuan," Semarang Pos, 19 Maret 2016, http://www.semarangpos.com/2016/01/28/kasus-perceraian-tergolong-tinggi-70perceraian-di-semarang-diajukan-perempuan-685408. html.

${ }^{3}$ Ibid.

4 Tyo, "Sebulan, 290 Janda baru di Semarang," Jawa Pos, 2 Maret 2016, http://www.radarsemarang.com/20160229/sebulan-290-janda-baru-di-semarang. html. 
kasus perceraian, dan pada tahun 2015 meningkat 3 kasus menjadi 3.119 kasus perceraian. ${ }^{5}$

Sebagian besar kasus perceraian di Pengadilan Agama Semarang pada tahun 2015 didominasi kasus perceraian yang diajukan oleh pihak isteri kepada suaminya, yang disebut dengan istilah cerai-gugat. Berdasarkan catatan statistik, perkara cerai-gugat antara tahun 2011-2015 naik sekitar $10 \%$ per tahun. Dari tahun ke tahun perkara cerai-gugat menunjukkan peningkatan yang sangat tinggi, apabila dibandingkan dengan perkara cerai-talak. Berdasarkan data yang ada, realita yang terjadi menunjukkan bahwa faktor dominan yang menjadi pemicu mengapa isteri berinisiatif mengajukan cerai-gugat adalah disebabkan tidak adanya keharmonisan lagi di antara suami-isteri.

\section{Kajian Pustaka}

Sekilas pembahasan teori tentang jenis pekerjaan, tingkat pendidikan dan macam-macam perceraian yaitu;

\section{Jenis Pekerjaan}

Jenis pekerjaan seseorang adalah dibuktikan oleh Surat Keputusan dari pejabat yang berwenang, sesuai dengan tingkat pekerjaan yang menjadi tugas dan tanggungjawabnya, baik sebagai Pegawai ASN maupun Pegawai No-ASN. Aparatur Sipil Negara yang selanjutnya disingkat ASN adalah profesi bagi pegawai negeri sipil dan pegawai pemerintah dengan perjanjian kerja yang bekerja pada instansi pemerintah. Pegawai Aparatur Sipil Negara yang selanjutnya disebut Pegawai ASN adalah pegawai negeri sipil dan pegawai pemerintah

5 Tyo, "Sebulan, 290 Janda baru di Semarang," Jawa Pos, 2 Maret 2016, http://www.radarsemarang.com/20160229/sebulan-290-janda-baru-di-semarang. html.

Rokhmadi, Pengaruh Jenis Pekerjaan dan ... 
dengan perjanjian kerja yang diangkat oleh pejabat pembina kepegawaian dan diserahi tugas dalam suatu jabatan pemerintahan atau diserahi tugas negara lainnya dan digaji berdasarkan peraturan perundang-undangan. Pegawai Negeri Sipil yang selanjutnya disingkat PNS adalah warga negara Indonesia yang memenuhi syarat tertentu, diangkat sebagai Pegawai ASN secara tetap oleh pejabat pembina kepegawaian untuk menduduki jabatan pemerintahan. ${ }^{6}$ Hal ini menunjukkan bahwa tingkat kualitas pekerjaan yang diembannya menjadi tugas dan tanggungjawabnya. Semakin tinggi jabatannya, maka semakin tinggi tugas dan tanggungjawabnya. Sebaliknya, semakin rendah jabatannya, maka semakin kecil resikonya. Oleh karena itu, seharusnya ada perbedaan antara ASN dan Non-ASN. Hal ini karena PNS adalah aparatur negara, penegak keadilan dan bisa menjadi contoh untuk masyarakat sebagai rakyatnya. Demikian pula dapat berimbas kepada kehidupan keluarganya, karena suami, isteri, dan anggota keluarga lainnya dalam rumah tangga dengan latar belakang tradisi, budaya, agama dan pekerjaan yang berbeda, perlu memahami dan mengekpresikan nilai-nilai positif budaya masing-masing dalam keshalehan verbal melalui ucapan dan tutur kata yang santun, sejuk, damai dan menyenangkan. Selain itu, mereka juga dapat menunjukannya dalam keshalehan sosial melalui perilaku sopansantun, pemaaf, saling menghormati, dan menghargai. ${ }^{7}$

${ }^{6}$ Undang-Undang RI Nomor 5 Tahun 2014 tentang Aparatur Sipil Negara, pasal 1 ayat 1, 2, dan 3.

7 Mohammad 'Azzam Manan, "Kekerasan Dalam Rumah Tangga dalam Perspektif Sosiologis”, Jurnal Legislasi Indonesia, Vol. 5 No. 3 (September 2008): 28-29. 
Dengan demikian, jenis pekerjaan seseorang akan berpengaruh positif terhadap sikap dan tingkah laku dalam berumah tangga, bermasyarakat maupun bernegara. Atas dasar itulah, kualitas jenis pekerjaan sangat berpengaruh terhadap kemajuan dan kemakmuran masyarakat dalam membentuk keluarga yang bahagia, sejahtera lahir dan batin, sehingga dapat mengurangi pemicu tindakan kekejaman jasmani dan kekejaman rohani dalam masyarakat.

Indikator perbedaan jenis pekerjaan adalah ASN dan Non-ASN. Yang dimaksud ASN adalah profesi bagi pegawai negeri sipil dan pegawai pemerintah dengan perjanjian kerja yang bekerja pada instansi pemerintah. Sedangkan yang dimaksud pegawai Non-ASN adalah jenis pekerjaan yang diluar ketentuan aturan-aturan negara dan menjadi tanggung jawab individu sendiri maupun lembaga non pemerintah.

\section{Tingkat Pendidikan}

Sebagaimana tersebut dalam Pasal 1 Undang-Undang Sistem Pendidikan Nasional menjelasakan bahwa "Pendidikan adalah usaha sadar dan terencana untuk mewujudkan suasana belajar dan proses pembelajaran agar peserta didik secara aktif mengembangkan potensi dirinya untuk memiliki kekuatan spiritual keagamaan, pengendalian diri, kepribadian, kecerdasan, akhlak mulia, serta keterampilan yang diperlukan dirinya, masyarakat, bangsa dan negara". Kemudian dalam Pasal 2 Undang-Undang tersebut juga dijelaskan bahwa yang dimaksud "Pendidikan nasional adalah pendidikan yang berdasarkan Pancasila dan Undang-Undang Dasar Negara Republik Indonesia Tahun 1945 
yang berakar pada nilai-nilai agama, kebudayaan nasional Indonesia dan tanggap terhadap tuntutan perubahan zaman". ${ }^{8}$

Tujuan pendidikan muncul dan bersumber dari tujuan hidup manusianya. Jelasnya, tujuan pendidikan merupakan kristalisasi dari tujuan hidup manusia yang akan memanfaatkan pendidikan tersebut. Tujuan hidup ini kemudian dimanifestasikan dalam ide-ide, pikiran, perbuatan serta harapan-harapan; antara lain bahwa output (keluaran) pendidikan yang diperlukan bagi sarana untuk mempertahankan kehidupan yang dapat dijadikan landasan konstitusional bagi tegaknya pendidikan sejati, yaitu yang fungsional, pragmatis dan berguna bagi kehidupannya. ${ }^{?}$

Terkait dengan potensi terjadinya tindakan perceraian yang dipengaruhi oleh faktor pendidikan, banyak hal positif dapat dipelajari dan diambil manfaatnya dari hubungan-hubungan sosial yang dibangun dalam masyarakat, terutama keluarga. Perceraian sesungguhnya dapat dihindarkan, jika suatu rumah tangga ditegakkan dengan menjalankan berbagai prinsip positif dan etika luhur berdasarkan fungsi anggota menurut hak dan kewajiban masingmasing. Menghapus tindakan perceraian dapat dimulai dengan menghilangkan sebab-sebab dan unsur-unsur pemicunya. Dalam kaitan ini, sekurang-kurang terdapat banyak cara dan usaha yang patut dilakukan agar perceraian terelakkan atau setidak-tidaknya dapat

${ }^{8}$ Undang-Undang Republik Indonesia Nomor 20 Tahun 2003 tentang Sistem Pendidikan Nasional.

${ }_{9}^{9}$ Ibid., hlm. vi. 
dikurangi intensitasnya. Di antaranya dengan memperkuat kualitas tingkat pendidikan dan jaringan sosial dalam masyarakat. ${ }^{10}$

Perubahan sosial masyarakat adalah dipengaruhi oleh kualitas masyarakatnya dalam menempuh kualitas tingkat pendidikannya. Hal ini sesuai dengan fungsi pendidikan sebagaimana yang telah di atur dalam Undang-Undang Republik Indonesia Nomor 20 Tahun 2003 tentang Sistem Pendidikan Nasional. Dalam Bab II Pasal 3 yang menjelaskan bahwa "Pendidikan nasional berfungsi mengembangkan kemampuan dan membentuk watak serta peradaban bangsa yang bermartabat dalam rangka mencerdaskan kehidupan bangsa, bertujuan untuk berkembangnya potensi peserta didik agar menjadi manusia yang beriman dan bertakwa kepada Tuhan Yang Maha Esa, berakhlak mulia, sehat, berilmu, cakap, kreatif, mandiri, dan menjadi warga negara yang demokratis serta bertanggung jawab". ${ }^{11}$

Atas dasar itulah, kualitas tingkat pendidikan sangat berpengaruh terhadap kemajuan dan kemakmuran masyarakat dalam membentuk keluarga yang bahagia, sejahtera lahir dan batin, sehingga dapat mengurangi pemicu tindakan perceraian dalam masyarakat. Dilihat dari sosiologi pendidikan, maka ilmu pengetahuan adalah ilmu yang mempelajari dan menyelidiki aspek sosio-kultural kehidupan manusia, misalnya ilmu ekonomi, ilmu hukum, ilmu pendidikan, psikologi, antropologi dan sosiologi. ${ }^{12}$

10 Mohammad 'Azzam Manan, "Kekerasan Dalam Rumah Tangga dalam Perspektif Sosiologis", Jurnal Legislasi Indonesia, Vol. 5 No. 3 (September 2008): 28-29.

${ }^{11}$ Undang-Undang Republik Indonesia Nomor 20 Tahun 2003 tentang Sistem Pendidikan Nasional.

12 Abu Ahmadi. Sosiologi Pendidikan (Surabaya: PT. Bina Ilmu, 1982).

Rokhmadi, Pengaruh Jenis Pekerjaan dan ... 
Dilihat juga dari ilmu perbandingan pendidikan bahwa perbandingan tingkat pendidikan seseorang akan berpengaruh terhadap kualitas hidupnya, sehingga mereka lebih bisa mengarahkan nasib masa depan menjadi lebih baik. Karena ilmu perbandingan pendidikan dapat juga diartikan sebagai studi tentang sistem dan cara pendidikan dan pengajaran di berbagai daerah, serta faktor-faktor yang mempengaruhinya. ${ }^{13}$ Sebagai contohnya, seseorang yang berpendidikan pada tingkat yang lebih rendah akan berpengaruh terhadap hasil kualitas outputnya di masyarakat. Misalnya, seseorang yang hanya lulus pendidikan dasar dan menengah akan berbeda dengan yang lulus pendidikan tinggi. Hal ini secara umum sesuai dengan tujuan pendidikan (das sain), tetapi belum tentu juga sesuai dengan kenyataannya (das Solen).

Indikator perbedaan tingkat pendidikan adalah berpendidikan tinggi dan berpendidikan dasar dan menengah. Yang dimaksud pendidikan tinggi adalah tingkat pendidikannya yang telah mencapai gelar sarjana (S.1,S.2, dan S.3), sedangkan yang dimaksud pendidikan dasar dan menengah adalah tingkat pendidikannya tidak mencapai gelar sarjana, mereka hanya lulus SD/MI sampai lulus SMA/MA.

\section{Macam-macam Perceraian}

Dalam perundang-undangan di Indonesia, ketentuan tentang pemeriksaan sengketa perkawinan atau dikenal dengan perceraian hanya dapat dilakukan di depan sidang Pengadilan setelah Pengadilan

${ }^{13}$ Arifin H.M. Ilmu Perbandingan Pendidikan. (Jakarta: PT. GoldenTerayon, 1987). 
yang bersangkutan berusaha dan tidak berhasil mendamaikan kedua belah pihak. ${ }^{14}$

Macam-macam perceraian di Indonesia hanya dikenal dengan istilah cerai talak dan cerai gugat. Adapun mengenai tata cara dan prosedur perceraian baik cerai talak dan cerai gugat adalah sebagai berikut:

\section{a. Cerai-Talak (Permohonan)}

Cerai-talak adalah permohonan perceraian yang dilakukan oleh suami kepada Pengadilan Agama untuk menceraikan isterinya, sebagaimana bunyi pasal 66 Undang-Undang Peradilan Agama yang menyatakan;

(1) Seorang suami yang beragama Islam yang akan menceraikan isterinya mengajukan permohonan kepada Pengadilan untuk mengadakan sidang guna menyaksikan ikrar talak.

(2) Permohonan sebagaimana dimaksud dalam ayat (1) diajukan kepada Pengadilan yang daerah hukumnya meliputi tempat kediaman termohon, kecuali apabila termohon dengan sengaja meninggalkan tempat kediaman yang ditentukan bersama tanpa izin pemohon.

(3) Dalam hal termohon bertempat kediaman di luar negeri, permohonan diajukan kepada Pengadilan yang daerah hukumnya meliputi tempat kediaman pemohon.

(4) Dalam hal pemohon dan termohon bertempat kediaman di luar negeri, maka permohonan diajukan kepada Pengadilan

14 Pasal 65 Undang-undang Peradilan Agama Nomor 7 Tahun 1989 jo. Pasal 115 Kompilasi Hukum Islam.

Rokhmadi, Pengaruh Jenis Pekerjaan dan ... 
yang daerah hukumnya meliputi tempat perkawinan mereka dilangsungkan atau kepada Pengadilan Agama Jakarta Pusat.

(5) Permohonan soal penguasaan anak, nafkah anak, nafkah isteri, dan harta bersama suami isteri dapat diajukan bersama-sama dengan permohonan cerai-talak ataupun sesudah ikrar talak diucapkan.

Sesuai dalam rumusan pasal 66 ayat (2) Undang-Undang Peradilan Agama Nomor 7 tahun 1989 tersebut bahwa tata cara dan prosedur cerai-talak yang menjadi tempat untuk mengajukan permohanan adalah Pengadilan yang daerah hukumnya meliputi tempat kediaman termohon (isteri), kecuali apabila termohon (isteri) dengan sengaja meninggalkan tempat kediaman yang ditentukan bersama tanpa izin pemohon. Hal ini mengandung maksud agar memberikan kemudahan dan keringanan kepada si isteri.

Kemudian dalam mengajukan permohonan perceraian yang diajukan oleh suami kepada isterinya sesuai dengan pasal 66 ayat (5) Undang-Undang Peradilan Agama Nomor 7 tahun 1989 dapat bersifat komulatif objektif atau gabungan tuntutan yang meliputi permohonan soal penguasaan anak, nafkah anak, nafkah isteri, dan harta bersama suami isteri. Hal ini dimaksudkan untuk menghemat waktu dan biaya, sehingga tuntas semua permasalahannya. ${ }^{15}$

15 Ahmad Rofiq. Hukum Perdata Islam di Indonesia. (Jakarta: PT. Rajawali Grafindo Persada, 2013) 
Permohonan sebagaimana yang dimaksud dalam Pasal 66 Undang-Undang Peradilan Agama Nomor 7 tahun 1989 memuat;

(a) Nama, umur, dan tempat kediaman pemohon, yaitu suami dan termohon, yaitu isteri.

(b) Alasan-alasan yang menjadi dasar cerai talak.

Sebagaimana pasal 19 Peraturan Pemerintah Nomor 9 Tahun 1975 jo. Pasal 116 Kompilasi Hukum Islam bahwa perceraian dapat terjadi karena alasan atau alasan-alasan;

(a) Salah satu pihak berbuat zina atau menjadi pemabuk, pemadat, penjudi, dan lain sebagainya yang sulit disembuhkan;

(b) Salah satu pihak meningalkan pihak lain selama 2 (dua) tahun berturut-turut tanpa izin pihak lain dan tanpa alasan yang sah atau karena hal lain diluar kemampuannya;

(c) Salah satu pihak mendapat hukuman penjara 5 (lima) tahun atau hukuman yang lebih berat setelah perkawinan berlangsung;

(d) Salah satu pihak melakukan kekejaman atau penganiayaan berat yang membahayakan pihak lain;

(e) Salah satu pihak mendapat cacat badan atau penyakit dengan akibat tidak dapat menjalankan kewajibannya sebagai suami/isteri;

(f) Antara suami dan isteri terus menerus terjadi perselisihan dan pertengkaran dan tidak ada harapan akan hidup rukun lagi dalam rumah tangga. 
Kemudian prosedur selanjutnya adalah pemeriksaan oleh Pengadilan Agama, sebagaimana Pasal 68 Undang-Undang Peradilan Agama Nomor 7 Tahun 1989 yang menjelaskan;

(1) Pemeriksaan permohonan cerai talak dilakukan oleh Majelis Hakim selambat-lambatnya 30 (tiga puluh) hari setelah berkas atau surat permohonan cerai talak didaftarkan di Kepaniteraan;

(2) Pemeriksaan permohonan cerai talak dilakukan dalam sidang tertutup.

\section{b. Cerai-Gugat (Gugatan)}

Cerai-gugat adalah perceraian yang dilakukan oleh isteri atau kuasa hukumnya kepada Pengadilan Agama untuk menggugat suaminya dengan membayar iwadl (tebusan) yang diserahkan kepada badan amalan Islam, maka jatuhlah talak 1 kepada suaminya.

Secara rinci tata cara dan prosedur cerai gugat sebagaimana telah diatur dalam pasal 73 Undang-Undang Nomor 7 Tahun 1989 tentang Peradilan Agama, yang menyatakan;

(1) Gugatan perceraian diajukan oleh isteri atau kuasanya kepada pengadilan yang daerah hukumnya meliputi tempat kediaman penggugat, kecuali apabila penggugat dengan sengaja meninggalkan tempat kediaman bersama tanpa izin tergugat.

(2) Dalam hal penggugat bertempat kediaman di luar negeri, gugatan perceraian diajukan kepada pengadilan yang daerah hukumnya meliputi tempat kediaman tergugat.

(3) Dalam hal penggugat dan tergugat bertempat kediaman di luar negeri, maka gugatan diajukan kepada pengadilan yang daerah 
hukumnya meliputi perkawinan mereka dilangsungkan atau kepada Pengadilan Agama Jakarta Pusat.

Lihat juga ketentuan dalam pasal 132 Kompilasi Hukum Islam jo. Pasal 20 Peraturan Pemerintah Nomor 9 Tahun 1975.

\section{Hipotesis}

Hipotesis dalam penelitian ini adalah ;

a. Masyarakat yang memiliki latar-belakang jenis pekerjaan Non-ASN akan cenderung lebih mudah melakukan perceraian, sedangkan masyarakat dengan latar-belakang jenis pekerjaan sebagai ASN cenderung akan lebih mampu mengendalikan diri dari melakukan perceraian.

b. Masyarakat yang tingkat pendidikan dasar dan menengah akan cenderung lebih mudah melakukan perceraian, sedangkan masyarakat yang tingkat pendidikan tinggi akan cenderung lebih mampu mengendalikan diri dari melakukan perceraian.

c. Masyarakat yang memiliki latar-belakang jenis pekerjaan Non-ASN dan tingkat pendidikan dasar dan menengah akan cenderung lebih mudah melakukan perceraian, sedangkan masyarakat dengan latarbelakang jenis pekerjaan sebagai ASN dan tingkat pendidikan tinggi akan cenderung lebih mampu mengendalikan diri dari melakukan perceraian.

\section{Metode Penelitian}

\section{JenisPenelitian}

Jenis penelitian yang digunakan dalam penelitian ini adalah penelitian lapangan (field research) yang bersifat kuantitatif dan kualitatif. 
Pendekatan kuantitatif merupakan pendekatan primer dalam penelitian ini, yaitu untuk mengetahui hubungan dan perbedaan pada variabel pengaruh jenis pekerjaan, dan tingkat pendidikan terhadap terjadinya perceraian di Pengadilan Agama Semarang Tahun 2015. Sedangkan

pendekatan kualitatif merupakan pendekatan sekunder, sehingga data kualitatif akan digunakan sebagai bahan analisis dari hasil kuantitatif.

\section{Identifikasi Variabel}

Adapun variable yang ditentukan oleh peneliti dalam analisis hubungan adalah:

1. Variable Independen (variabel $\mathrm{X}$ ), merupakan variable inti atau variable bebas yaitu jenis pekerjaan (ASN dan Non-ASN) dan tingkat pendidikan (tinggi, dan dasar dan menengah).

2. Variabel Dependen (variable Y), merupakan variable terikat yaitu perceraian (cerai-talak dan cerai-gugat).

\section{Definisi Operasional Variabel}

Jenis pekerjaan adalah ASN dan Non-ASN. Yang dimaksud Pegawai Aparatur Sipil Negara yang selanjutnya disebut Pegawai ASN adalah pegawai negeri sipil dan pegawai pemerintah dengan perjanjian kerja yang diangkat oleh pejabat pembina kepegawaian dan diserahi tugas dalam suatu jabatan pemerintahan atau diserahi tugas negara lainnya dan digaji berdasarkan peraturan perundang-undangan. Sedangkan yang dimaksud pegawai Non-ASN adalah jenis pekerjaan yang diluar ketentuan aturan-aturan negara dan menjadi tanggung jawab individu sendiri maupun lembaga non pemerintah. 
Tingkat pendidikan adalah pendidikan tinggi, dan pendidikan dasar dan menengah. Yang dimaksud pendidikan tinggi adalah tingkat pendidikannya yang telah mencapai gelar sarjana (S.1, S.2, dan S.3), sedangkan yang dimaksud pendidikan dasar dan menengah adalah tingkat pendidikannya tidak mencapai gelar sarjana, mereka hanya lulus $\mathrm{SD} / \mathrm{MI}$, SMP/MTs sampai lulus SMA/MA. Perubahan sosial masyarakat adalah dipengaruhi oleh kualitas masyarakatnya dalam menempuh kualitas tingkat pendidikannya. Hal ini sesuai dengan fungsi pendidikan sebagaimana yang telah di atur dalam Undang-Undang Republik Indonesia Nomor 20 Tahun 2003 tentang Sistem Pendidikan Nasional. Dalam Bab II Pasal 3 yang menjelaskan bahwa "Pendidikan nasional berfungsi mengembangkan kemampuan dan membentuk watak serta peradaban bangsa yang bermartabat dalam rangka mencerdaskan kehidupan bangsa, bertujuan untuk berkembangnya potensi peserta didik agar menjadi manusia yang beriman dan bertakwa kepada Tuhan Yang Maha Esa, berakhlak mulia, sehat, berilmu, cakap, kreatif, mandiri, dan menjadi warga negara yang demokratis serta bertanggung jawab". ${ }^{16}$

Atas dasar itulah, kualitas tingkat pendidikan sangat berpengaruh terhadap kemajuan dan kemakmuran masyarakat dalam membentuk keluarga yang bahagia, sejahtera lahir dan batin, sehingga dapat mengurangi pemicu tindakan perceraian dalam masyarakat. Dilihat dari sosiologi pendidikan, maka ilmu pengetahuan adalah ilmu yang mempelajari dan menyelidiki aspek sosio-kultural kehidupan manusia,

\footnotetext{
16 Undang-Undang Republik Indonesia Nomor 20 Tahun 2003 tentang Sistem Pendidikan Nasional.
}

Rokhmadi, Pengaruh Jenis Pekerjaan dan ... 
misalnya ilmu ekonomi, ilmu hukum, ilmu pendidikan, psikologi, antropologi dan sosiologi. ${ }^{17}$

Dilihat juga dari ilmu perbandingan pendidikan bahwa perbandingan tingkat pendidikan seseorang akan berpengaruh terhadap kualitas hidupnya, sehingga mereka lebih bisa mengarahkan nasib masa depan menjadi lebih baik. Karena ilmu perbandingan pendidikan dapat juga diartikan sebagai studi tentang sistem dan cara pendidikan dan pengajaran di berbagai daerah, serta faktor-faktor yang mempengaruhinya. ${ }^{18}$ Sebagai contohnya, seseorang yang berpendidikan pada tingkat yang lebih rendah akan berpengaruh terhadap hasil kualitas outputnya di masyarakat. Misalnya, seseorang yang hanya lulus SMA kebawah akan berbeda dengan yang lulus S.1, dan seseorang yang hanya lulus S.1 akan berbeda dengan yang lulus S.2 maupun S.3. Hal ini secara umum sesuai dengan tujuan pendidikan (das sain), tetapi belum tentu juga sesuai dengan kenyataannya (das Solen).

\section{Populasi dan Sampel}

\section{Populasi}

Populasi adalah wilayah generalisasi yang terdiri atas objek/subjek yang mempunyai kuantitas dan karakteristik tertentu yang ditetapkan oleh peneliti untuk dipelajari dan kemudian ditarik kesimpulan. ${ }^{19}$

\footnotetext{
${ }^{17}$ Abu Ahmadi, Sosiologi Pendidikan (Surabaya: PT. Bina Ilmu, 1982), 11-12

18 Arifin H.M. Ilmu Perbandingan Pendidikan (Jakarta: PT. GoldenTerayon, 1987), 8

${ }^{19}$ Sugiyono, Statistik. Untuk Penelitian (Bandung: CV. Alfabeta, 2007), 61.
} 
Menurut Burhan Bungin, bahwa populasi adalah keseluruhan (universum) dari objek penelitian yang dapat berupa objek-objek yang bisa menjadi sumber data. ${ }^{20}$

Populasi dalam penelitian ini adalah seluruh pasangan suamiisteri (pasutri) yang melakukan perceraian di Pengadilan Agama Semarang pada Tahun 2015.

Berdasarkan informasi dari bagian Humas Pengadilan Agama Kelas 1-A Semarang, M. Sukri bahwa pada tahun 2015, jumlah perceraian di Ibu Kota Provinsi Jawa Tengah itu mencapai 3.119 perkara dan semuanya telah diputuskan dalam persidangan. Dari data 3.119 perkara tersebut hampir 70,439\% lebih atau sebanyak 2.197 perkara perceraian diajukan oleh pihak perempuan (isteri), sedangkan sisanya $29,56 \%$ atau sebanyak 922 perkara adalah cerai talak atau cerai yang diajukan dari pihak laki-laki (suami). Dari data tersebut juga tercatat, jika tingkat perceraian tertinggi terjadi pada bulan Agustus 2015 dengan jumlah perkara cerai gugat oleh pihak isteri sebanyak 235 perkara dan perkara cerai talak oleh pihak suami sebanyak 95 perkara saja. ${ }^{21}$

\section{Sampel}

Sampel adalah bagian dari jumlah dan karakteristik yang dimiliki oleh populasi tersebut. Apa yang dipelajari dari sampel itu, kesimpulannya akan diberlakukan untuk populasi. Sampel yang diambil

${ }^{20}$ Burhan Bungin, Metode Penelitian Kuantitatif, (Jakarta: Prenada Media Group, 2005), 141.

21 Samsul, "Kasus perceraian tergolong tinggi, 70\% perceraian di Semarang diajukan perempuan," Semarang Pos, 19 Maret 2016, http://www.semarangpos.com/2016/01/28/kasus-perceraian-tergolong-tinggi-70perceraian-di-semarang-diajukan-perempuan-685408. html.

Rokhmadi, Pengaruh Jenis Pekerjaan dan ... 
dari populasi haruslah representatif (mewakili) yaitu benar-benar mencerminkan populasinya. ${ }^{22}$ Sampel adalah bagian dari jumlah dan karakteristik yang dimiliki oleh populasi tersebut. ${ }^{23}$

Sampel dalam penelitian ini diambil melalui teknik purposive random sampling yaitu pengambilan sampel didasarkan pada tujuan atau ciri dari penelitian. Dalam penelitian ini terdapat variabel yang terkait dengan pasutri yang melakukan perceraian baik cerai-talak maupun cerai-gugat di Pengadilan Agama Semarang pada Tahun 2015 yang dilakukan oleh pasangan suami-isteri dalam perkara khusus Peraturan Pemerintah Nomor 10 Tahun 1983 jo. Peraturan Pemerintah Nomor 45 Tahun 1990. Dengan demikian, jumlah seluruh sampel dalam penelitian ini adalah 4.32\% dari 3119 yaitu 135 perkara yang diterima dalam persidangan pada Tahun 2015.

\section{Deskripsi Data Penelitian}

Penelitian ini dilaksanakan di Pengadilan Agama Semarang dengan subjek penelitian khususnya para pasangan suami-isteri mengenai perkara khusus Peraturan Pemerintah Nomor 10 Tahun 1983 jo. Peraturan Pemerintah Nomor 45 Tahun 1990 yang melakukan perceraian pada Pengadilan Agama Semarang Tahun 2015. Analisis deskripsi bertujuan untuk memberikan deskripsi subjek penelitian berdasarkan data dari variabel yang diperoleh dari kelompok subjek yang diteliti dan tidak dimaksudkan untuk pengujian hipotesis.

22 Burhan Bungin, Metode Penelitian Kuantitatif, (Jakarta: Prenada Media Group, 2005), 81.

${ }^{23}$ Sugiyono, Statistik. Untuk Penelitian (Bandung: CV. Alfabeta, 2007). 
Berdasarkan hasil analisis deskripsi terhadap data penelitian baik secara kuantitatif maupun kualitatif dapat dideskripsikan data masingmasing variable sebagai berikut:

\section{Deskripsi Perceraian}

Variabel jenis pekerjaan dalam penelitian ini merupakan gabungan dari data jenis pekerjaan ASN dan jenis pekerjaan NonASN. Jenis pekerjaan berasal dari skor ASN dan Non-ASN yang melakukan perceraian baik cerai-talak maupun cerai-gugat.

Berdasarkan hasil analisis deskripsi dengan program IBM SPSS Statistic 21 for Windows mengenai jenis pekerjaan dapat dilihat dari table 1 dibawah ini.

Tabel 1:

Deskripsi Data Perceraian Statistics

\begin{tabular}{llccc}
\hline & & $\begin{array}{c}\text { Jenis } \\
\text { Pekerjaan }\end{array}$ & $\begin{array}{c}\text { Tingkat } \\
\text { Pendidikan }\end{array}$ & Perceraian \\
\hline $\mathrm{N}$ & Valid & 135 & 135 & 135 \\
& Missing & 0 & 0 & 0 \\
& Mean & 1.38 & 1.78 & 1.53 \\
Median & 1.00 & 2.00 & 2.00 \\
Mode & 1 & 2 & 2 \\
Std. Deviation & .487 & .417 & .501 \\
Minimum & 1 & 1 & 1 \\
Maximum & 2 & 2 & 2 \\
Sum & 186 & 240 & 206 \\
\hline
\end{tabular}

Berdasarkan pada tabel tersebut dapat dijelaskan bahwa pasutri yang melakukan perceraian memiliki rata-rata (mean) sebesar 1,53, standar deviasi 0,501, dengan skor minimal 1 dan maksimal 2.

\section{a. Jenis Pekerjaan}

Jenis pekerjaan dilihat dari ASN dan Non-ASN yang melakukan perceraian di Pengadilan Agama Semarang Tahun 2015. Berdasarkan Rokhmadi, Pengaruh Jenis Pekerjaan dan ... 
hasil analisis deskripsi dengan program IBM SPSS 21 for Windows mengenai data jenis pekerjaan dapat dilihat dari tabel 2 dibawah ini.

Tabel 2:

Deskripsi Data Jenis Pekerjaan Statistics

\begin{tabular}{c|c|c|c|c|c}
\hline \multicolumn{2}{c}{ Jenis Pekerjaan } & Frequency & Percent & $\begin{array}{c}\text { Valid } \\
\text { Percent }\end{array}$ & $\begin{array}{c}\text { Cumulative } \\
\text { Percent }\end{array}$ \\
\hline \multirow{4}{*}{ Valid } & ASN & 84 & 62.2 & 62.2 & 62.2 \\
& Non- & 51 & 37.8 & 37.8 & 100.0 \\
& ASN & & & & \\
\cline { 2 - 6 } & Total & 135 & 100.0 & 100.0 & \\
\hline
\end{tabular}

Berdasarkan pada tabel tersebut dapat dijelaskan bahwa pasangan suami-isteri yang melakukan perceraian memiliki rata-rata (mean) jenis pekerjaan sebesar 1,38 dengan batas minimum 1 dan maksimum 2.

Dilihat dari jumlah pasangan suami-isteri yang melakukan perceraian yang berstatus sebanyak ASN $84(62,2 \%)$ pasutri dan yang bersatus Non-ASN sebanyak 51(37,8\%) pasutri. Dengan demikian, dapat disimpulkan bahwa jenis pekerjaan yang berstatus ASN berada dalam kategori tinggi daripada jenis pekerjaan yang berstatus NonASN, karena lebih dari 50\%.

\section{b. Tingkat Pendidikan}

Tingkat pendidikan dilihat dari berpendidikan tinggi dan berpendidikan dasar dan menengah yang melakukan perceraian di Pengadilan Agama Semarang pada Tahun 2015. Skoring dibuat dengan angka 1 untuk pendidikan tinggi dan angka 2 untuk pendidikan dasar dan menengah. Berdasarkan hasil analisis deskripsi dengan program IBM SPSS 21 for Windows mengenai data jenis pekerjaan dapat dilihat dari tabel 3 dibawah ini. 
Tabel 3:

Deskripsi Data Tingkat Pendidikan Statistics

\begin{tabular}{|c|c|c|c|c|c|}
\hline & $\begin{array}{c}\text { Tingkat } \\
\text { Pendidikan }\end{array}$ & Frequency & Percent & Valid Percent & $\begin{array}{c}\text { Cumulative } \\
\text { Percent }\end{array}$ \\
\hline \multirow[t]{2}{*}{ Valid } & $\begin{array}{c}\text { Tinggi } \\
\text { Dasar dan } \\
\text { Menengah }\end{array}$ & $\begin{array}{c}30 \\
105\end{array}$ & $\begin{array}{l}22.2 \\
77.8\end{array}$ & $\begin{array}{l}22.2 \\
77.8\end{array}$ & $\begin{array}{c}22.2 \\
100.0\end{array}$ \\
\hline & Total & 135 & 100.0 & 100.0 & \\
\hline
\end{tabular}

Berdasarkan pada tabel tersebut dapat dijelaskan bahwa pasangan suami-isteri yang melakukan perceraian memiliki rata-rata (mean) tingkat pendidikan sebesar 1,78 dengan batas minimum 1 dan maksimum 2.

Dilihat dari jumlah pasangan suami-isteri yang melakukan perceraian yang berstatus pendidikan tinggi sebanyak $30(22,2 \%)$ pasutri dan yang bersatus pendidikan dasar dan menengah sebanyak $105(77,8 \%)$ pasutri. Dengan demikian, dapat disimpulkan bahwa tingkat pendidikan tinggi berada dalam kategori rendah daripada tingkat pendidikan dasar dan menengah, karena kurang dari 50\%.

\section{c. Perceraian}

Perceraian dilihat dari cerai-talak dan cerai-gugat. Cerai-talak yaitu permohonan perceraian dari pihak suami, sedangkan cerai-gugat yaitu gugatan perceraian dari pihak isteri yang melakukan perceraian di Pengadilan Agama Semarang pada Tahun 2015. Skoring dibuat dengan angka 1 untuk cerai-talak dan angka 2 untuk cerai-gugat. Berdasarkan hasil analisis deskripsi dengan program IBM SPSS 21 for Windows mengenai data perceraian dapat dilihat dari tabel 4 dibawah ini.

Rokhmadi, Pengaruh Jenis Pekerjaan dan ... 
Tabel 4:

Deskripsi Data Perceraian Statistics

\begin{tabular}{cccccc}
\hline & Perceraian & Frequency & Percent & $\begin{array}{c}\text { Valid } \\
\text { Percent }\end{array}$ & $\begin{array}{c}\text { Cumulative } \\
\text { Percent }\end{array}$ \\
\hline \multirow{3}{*}{ Valid } & Cerai-Talak & 64 & 47.4 & 47.4 & 47.4 \\
& Cerai-Gugat & 71 & 52.6 & 52.6 & 100.0 \\
& Total & 135 & 100.0 & 100.0 & \\
\hline
\end{tabular}

Berdasarkan pada tabel tersebut dapat dilihat dari jumlah pasangan suami-isteri yang melakukan perceraian yang berstatus ceraitalak sebanyak $64(47,4 \%)$ pasutri dan yang bersatus cerai-gugat sebanyak $71(52,6 \%)$ pasutri. Dengan demikian, dapat disimpulkan bahwa perceraian yang berstatus cerai- talak berada dalam kategori lebih rendah daripada cerai-gugat, karena lebih dari 50\%.

Hal ini menunjukan bahwa frekuensi jumlah pasangan suamiisteri yang melakukan perceraian di Pengadilan Agama Semarang tahun 2015 dapat dilihat juga dari tabel 5 dibawah ini.

Tabel 5:

Frekuensi Data Jenis Pekerjaan dan Tingkat Pendidikan Pasutri yang melakukan Perceraian

\begin{tabular}{lcccrrrr}
\hline Descriptive Statistics & N & $\begin{array}{c}\text { Mini- } \\
\text { mum }\end{array}$ & $\begin{array}{c}\text { Maxi- } \\
\text { mum }\end{array}$ & Sum & Mean & $\begin{array}{c}\text { Std. } \\
\text { Deviation }\end{array}$ \\
\hline Jenis Pekerjaan & 135 & 1 & 2 & 186 & 1.38 & .487 \\
Tingkat Pendidikan & 135 & 1 & 2 & 240 & 1.78 & .417 \\
Perceraian & 135 & 1 & 2 & 206 & 1.53 & .501 \\
Valid N (listwise) & 135 & & & & & & \\
\hline
\end{tabular}

Berdasarkan tabel tersebut dapat dijelaskan bahwa sebanyak 135 pasutri melakukan perceraian, baik cerai-talak maupun cerai-gugat. Pada tabel tersebut dapat dijelaskan bahwa pasutri jika dilihat dari jenis pekerjaan yang melakukan perceraian memiliki rata-rata (mean) sebesar 1,38, standar deviasi 0,487, dengan skor minimal1 dan maksimal 2 . 
Sedangkan pasutri jika dilihat dari tingkat pendidikan yang melakukan perceraian memiliki rata-rata (mean) sebesar 1,78, standar deviasi 0,417, dengan skor minimal 1 dan maksimal 2. dan berdasarkan pada tabel tersebut dapat dijelaskan bahwa pasutri yang melakukan perceraian memiliki rata-rata (mean) sebesar 1,53, standar deviasi 0,501, dengan skor minimal 1 dan maksimal 2 .

\section{Pengujian Hipotesis Penelitian}

Pengujian hipotesis penelitian bertujuan untuk membuktikan kebenaran dari hipotesis yang diajukan. Dalam penelitian ini terdapat tiga hipotesis yang diajukan dengan penjelasan sebagai berikut:

\section{Uji T Independen}

\section{a. Jenis Pekerjaan}

Analisis statistic independent sampel t-test dalam penelitian ini digunakan untuk menguji hipotesis pertama. Analisis parametric kini digunakan karena data pada variable jenis pekerjaan memenuhi prasyarat yaitu berdistribusi normal dan homogen.

Hipotesispertama adalah ada perbedaan yang signifikan jenis pekerjaan pasangan suami-isteri yang melakukan perceraian antara ASN dan Non-ASN di Pengadilan Agama Tahun 2015.

Analisis ini dilakukan dengan bantuan program IBM SPSS 21 for windows dengan hasil sebagai berikut dalam table 6 dibawah ini. 
Tabel 6:

Hasil Analisis Uji T Independen

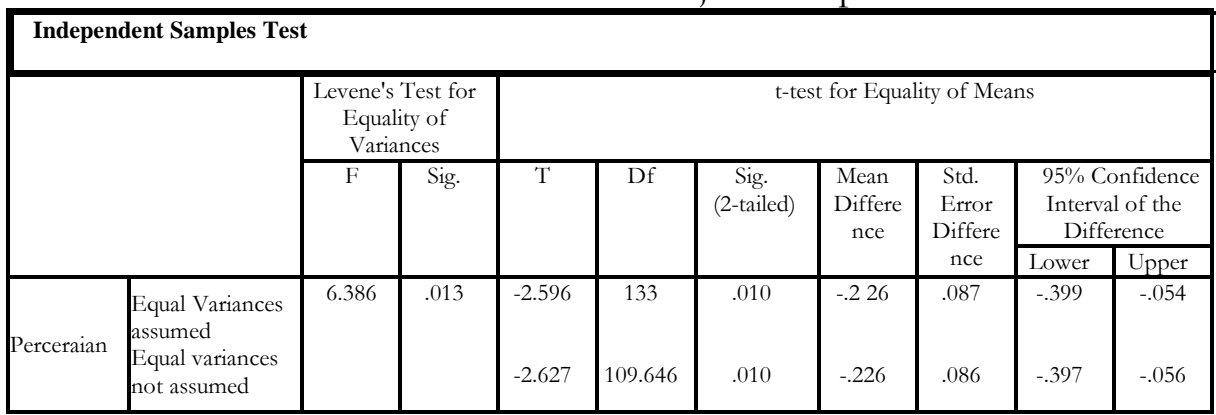

Berdasarkan hasil dari analisis uji t independen pada table diatas diperoleh nilai t sebesar -2,596 dengan taraf signifikansi sebesar 0,010 $(\mathrm{p}<0,05)$ yang menunjukan bahwa hipotesis diterima yaitu ada perbedaan yang signifikan jenis pekerjaan pasangan suamiisteri yang melakukan perceraian antara ASN dan Non-ASN di Pengadilan Agama Tahun 2015.

Dengan demikian, kesimpulan dalam penelitian ini secara deskriptif dengan analisis uji t independen adalah bahwa pengaruh perbedaan jenis pekerjaan ASN terhadap tingkat perceraian di Pengadilan Agama Semarang hasilnya lebih tinggi Non-ASN yang melakukan perceraian dengan independent samples test, skornya 2,596 dengan taraf signifikansi 0,010 lebih kecil dari 0,05 (0,010< $0,05)$.

\section{b. Tingkat Pendidikan}

Analisis statistic independent sampel t-test dalam penelitian ini digunakan untuk menguji hipotesis kedua. Analisis parametric kini 
digunakan karena data pada variable tingkat pendidikan memenuhi prasyarat yaitu berdistribusi normal dan homogen.

Hipotesis kedua adalah ada perbedaan yang signifikan tingkat pendidikan pasangan suami-isteri yang melakukan perceraian antara berpendidikan tinggi dan berpendidikan dasar dan menengah di Pengadilan Agama Tahun 2015.

Analisis ini dilakukan dengan bantuan program IBM SPSS 21 for windows dengan hasil sebagai berikut dalam table 7 dibawah ini.

Tabel 7:

Hasil Analisis Uji T Independen

\begin{tabular}{|c|c|c|c|c|c|c|c|c|c|c|}
\hline \multicolumn{11}{|c|}{ Independent Samples Test } \\
\hline & & \multicolumn{2}{|c|}{$\begin{array}{c}\text { Levene's Test for Equality of } \\
\text { Variances }\end{array}$} & \multicolumn{7}{|c|}{ t-test for Equality of Means } \\
\hline & & \multirow[t]{2}{*}{$\mathrm{F}$} & \multirow[t]{2}{*}{ Sig. } & \multirow[t]{2}{*}{$\mathrm{T}$} & \multirow[t]{2}{*}{ Df } & \multirow[t]{2}{*}{$\begin{array}{c}\text { Sig. } \\
\text { (2-tailed) }\end{array}$} & \multirow[t]{2}{*}{$\begin{array}{l}\text { Mean } \\
\text { Difference }\end{array}$} & \multirow[t]{2}{*}{$\begin{array}{l}\text { Std. Error } \\
\text { Difference }\end{array}$} & \multicolumn{2}{|c|}{$\begin{array}{l}\text { 95\% Confidence } \\
\text { Interval of the } \\
\text { Difference }\end{array}$} \\
\hline & & & & & & & & & Lower & Upper \\
\hline & $\begin{array}{l}\text { Equal } \\
\text { variances } \\
\text { assumed }\end{array}$ & 3.964 & .049 & -2.430 & 133 & .016 & -.248 & .102 & -.449 & -.046 \\
\hline Perceraian & \begin{tabular}{|l|} 
Equal \\
variances \\
not \\
assumed
\end{tabular} & & & -2.476 & 48.171 & .017 & -.248 & .100 & -.449 & -.047 \\
\hline
\end{tabular}

Berdasarkan hasil dari analisis uji $\mathrm{t}$ independen pada table diatas diperoleh nilai $\mathrm{t}$ sebesar -2.430 dengan taraf signifikansi sebesar $0,016(\mathrm{p}<0,05)$ yang menunjukan bahwa hipotesis diterima yaitu ada perbedaan yang signifikan tingkat pendidikan pasangan suami-isteri yang melakukan perceraian antara berpendidikan tinggi dan berpendidikan dasar dan menengah di Pengadilan Agama Tahun 2015.

Dengan demikian, simpulan dalam penelitian ini secara deskriptif dengan analisis uji $\mathrm{t}$ independen adalah bahwa pengaruh perbedaan tingkat pendidikan tinggi dan pendidikan dasar dan menengah terhadap tingkat perceraian di Pengadilan Agama 
Semarang hasilnya lebih tinggi yang berpendidikan dasar dan menengah yang melakukan perceraian dengan uji sampel independen (independent samples test), skornya -2,430 dengan taraf signifikansi 0,016 lebih kecil dari $0,05(0,016<0,05)$.

\section{Uji Hipotesis dengan Analisis Regresi Binari Logistik}

Uji analisis regresi binari logistik digunakan untuk menganalisis hipotesis pertama dan kedua. Model regresi ini dipilih karena data pada variables not in the equation berbentuk nominal dari jenis pekerjaan dan tingkat pendidikan pasangan suami-isteri yang melakukan perceraian di Pengadilan Agama Tahun 2015.

Analisis ini dilakukan dengan bantuan program IBM SPSS 21 for windows dengan hasil sebagai berikut dalam table 8 dibawah ini.

Tabel 8:

Hasil Analisis Regresi Binari Logistik

\begin{tabular}{|c|c|c|c|c|c|}
\hline \multicolumn{6}{|c|}{ Variables not in the Equation } \\
\hline & & & Score & Df & Sig. \\
\hline \multirow{3}{*}{ Step 0} & \multirow{2}{*}{ Variables } & JP & 6.512 & 1 & .011 \\
\hline & & TP & 5.738 & 1 & .017 \\
\hline & \multicolumn{2}{|r|}{ Overall Statistics } & 10.571 & 2 & .005 \\
\hline
\end{tabular}

Berdasarkan hasil dari analisis regresi binari logistik pada table diatas diperoleh jenis pekerjaan dengan skor sebesar 6.512 dengan taraf signifikansi sebesar $0,011(\mathrm{p}<0,05)$ yang menunjukkan bahwa hipotesis pertama diterima yaitu ada perbedaan yang signifikan jenis pekerjaan antara ASN dan Non-ASN pasangan suami-isteri yang melakukan perceraian di Pengadilan Agama Tahun 2015.

Kemudian dari hasil dari analisis regresi binari logistik pada table diatas diperoleh tingkat pendidikan dengan skor sebesar 5.738 dengan 
taraf signifikansi sebesar 0,017 $(\mathrm{p}<0,05)$ yang menunjukkan bahwa hipotesis kedua diterima yaitu ada perbedaan yang signifikan tingkat pendidikan antara pendidikan tinggi dan tingkat pendidikan dasar dan menengah pasangan suami-isteri yang melakukan perceraian di Pengadilan Agama Tahun 2015.

Dengan demikian, simpulan dalam penelitian ini secara analisis regresi binari logistik adalah sebagai berikut;

1. Hipotesis pertama diterima bahwa masyarakat yang memiliki latarbelakang jenis pekerjaan Non-ASN akan cenderung lebih mudah melakukan perceraian, sedangkan masyarakat dengan latar-belakang jenis pekerjaan sebagai ASN cenderung akan lebih mampu mengendalikan diri dari melakukan perceraian, karena variabel tidak dalam persamaan (variables not in the equation) skornya 6,512 dengan taraf signifikansi 0,011 lebih kecil dari 0,05 $(0,011<0,05)$.

2. Hipotesis kedua diterima bahwa masyarakat yang tingkat pendidikan dasar dan menengah akan cenderung lebih mudah melakukan perceraian, sedangkan masyarakat yang tingkat pendidikan tinggi akan cenderung lebih mampu mengendalikan diri dari melakukan perceraian, karena variabel tidak dalam persamaan skornya 5,738 dengan taraf signifikansi 0,017 lebih kecil dari 0,05 $(0,017<0,05)$.

Adapun hipotesis ketiga yang diajukan dalam penelitian ini adalah ada hubungan yang signifikan antara jenis pekerjaan dan tingkat pendidikan terhadap perceraian pasangan suami-isteri yang melakukan perceraian di Pengadilan Agama Tahun 2015. Pengujian hipotesis ketiga 
ini menggunakan analisis regresi logistik dengan bantuan program IBM SPSS 21 for Windows dengan hasil pada table 9 dibawah ini.

Tabel 9:

Hasil Analisis Regresi Logistik Omnibus

\begin{tabular}{|l|l|r|r|r|}
\hline \multicolumn{1}{|c|}{ Tests of Model Coefficients } & Chi-square & Df & \multicolumn{1}{c|}{ Sig. } \\
\hline \multirow{3}{*}{ Step 1} & Step & 10.861 & 2 & .004 \\
\cline { 2 - 5 } & Block & 10.861 & 2 & .004 \\
\cline { 2 - 5 } & Model & 10.861 & 2 & .004 \\
\hline
\end{tabular}

Berdasarkan hasil yang terdapat dalam tabel tersebut diperoleh nilai Chi-Square 10,861 dengan signifikansi 0,004, sehingga berada dibawah $0,05(\mathrm{p}<0,05)$. Hal ini menunjukkan bahwa hipotesis dalam penelitian ini diterima yang berarti bahwa ada hubungan yang signifikan antara jenis pekerjaan dan tingkat pendidikan terhadap terjadinya perceraian pada Pengadilan Agama Semarang Tahun 2015.

Dengan demikian, simpulan dalam penelitian ini secara analisis regresi binari logistik adalah hipotesis ketiga diterima bahwa masyarakat yang memiliki latar-belakang jenis pekerjaan Non-ASN dan tingkat pendidikan dasar dan menengah akan cenderung lebih mudah melakukan perceraian, sedangkan masyarakat dengan latar-belakang jenis pekerjaan sebagai ASN dan tingkat pendidikan tinggi akan cenderung lebih mampu mengendalikan diri dari melakukan perceraian, karena variabel tidak dalam persamaan skornya 10,861 dengan taraf signifikansi 0,004 lebih kecil dari 0,05 $(0,004<0,05)$.

\section{Pembahasan Hasil Penelitian}

Berdasarkan hasil penelitian dengan analisis uji $\mathrm{t}$ independen mengenai pengaruh perbedaan jenis pekerjaan ASN dan Non-ASN terhadap tingkat perceraian di Pengadilan Agama Semarang hasilnya lebih tinggi Non-ASN 
yang melakukan perceraian dengan independent samples test, skornya 2,596 dengan taraf signifikansi 0,010 lebih kecil dari 0,05 $(0,010<0,05)$.

Meskipun ada juga pasangan suami-isteri yang ASN melakukan perceraian di Pengadilan Agama Tahun 2015, skornya adalah -2,627 dengan taraf signifikansi 0,010 lebih kecil dari $0,05(0,010<0,05)$. Hal ini menunjukkan bahwa masih ada kecenderungan ASN yang melakukan perceraian walaupun tidak ada ijin dari atasannya. Dari hasil tersebut dapat dikatakan sangat memprihatinkan, karena tanpa ijin atasan masih bisa melakukan perceraian dan Pengadilan Agama mengabulkannnya.

Sedangkan hasil penelitian dengan analisis uji t independen mengenai pengaruh perbedaan tingkat pendidikan tinggi dan pendidikan dasar dan menengah terhadap tingkat perceraian diperoleh nilai $t$ sebesar -2.430 dengan taraf signifikansi sebesar $0,016(p<0,05)$ yang menunjukan bahwa hipotesis diterima yaitu ada perbedaan yang signifikan tingkat pendidikan pasangan suami-isteri yang melakukan perceraian antara berpendidikan tinggi dan berpendidikan dasar dan menengah di Pengadilan Agama Tahun 2015.

Meskipun ada juga pasangan suami-isteri yang berpendidikan tinggi melakukan perceraian di Pengadilan Agama Tahun 2015, skornya adalah 2,476 dengan taraf signifikansi 0,017 lebih kecil dari 0,05 $(0,010<0,05)$. Hal ini menunjukkan bahwa masih ada kecenderungan berpendidikan tinggi yang melakukan perceraian, sehingga tingkat pendidikan tidak terlalu berpengaruh terhadap proses perceraian pasangan suami-isteri. Dari hasil tersebut dapat dikatakan sangat memprihatinkan, karena gelar kesarjanaan belum dapat mempengaruhi untuk membina rumah tangga yang bahagia dan kekal, sehingga masih melakukan perceraian dan Pengadilan Agama tetap mengabulkannnya tanpa mempertimbangkannya.

Kemudian berdasarkan hasil dari analisis regresi binari logistik dapat diperoleh jenis pekerjaan dengan skor sebesar 6.512 dengan taraf signifikansi sebesar $0,011 \quad(\mathrm{p}<0,05)$ yang menunjukkan bahwa ada 
perbedaan yang signifikan jenis pekerjaan antara ASN dan Non-ASN pasangan suami-isteri yang melakukan perceraian di Pengadilan Agama Tahun 2015, dan tingkat pendidikan dengan skor sebesar 5.738 dengan taraf signifikansi sebesar $0,017(\mathrm{p}<0,05)$ yang menunjukkan bahwa ada perbedaan yang signifikan tingkat pendidikan antara berpendidikan tinggi dan berpendidikan dasar dan menengah pasangan suami-isteri yang melakukan perceraian di Pengadilan Agama Tahun 2015.

Meskipun jumlah keseluruhan pasangan suami-isteri baik dari jenis pekerjaan maupun tingkat pendidikan yang melakukan perceraian di Pengadilan Agama Tahun 2015, skornya adalah 10.571 dengan taraf signifikansi 0,005 lebih kecil dari 0,05 $(0,005<0,05)$. Hal ini menunjukkan bahwa masih ada kecenderungan pasangan suami-isteri baik dari jenis pekerjaan maupun tingkat pendidikan yang melakukan perceraian di Pengadilan Agama Tahun 2015 walaupun tidak ada ijin dari atasannya dan memiliki tingkat pendidikan tinggi atau gelar sarjana. Dari hasil tersebut dapat dikatakan sangat memprihatinkan, karena tanpa ijin atasannya dan memiliki tingkat pendidikan tinggi atau sarjana masih melakukan perceraian dan Pengadilan Agama mengabulkannya.

\section{Kesimpulan}

Berdasarkan hasil penelitian dapat disimpulkan sebagai berikut:

1. Hipotesis pertama diterima bahwa masyarakat yang memiliki latarbelakang jenis pekerjaan Non-ASN akan cenderung lebih mudah melakukan perceraian, sedangkan masyarakat dengan latar-belakang jenis pekerjaan sebagai ASN cenderung akan lebih mampu mengendalikan diri dari melakukan perceraian, karena variabel tidak dalam persamaan (variables not in the equation) skornya 6,512 dg taraf signifikansi 0,011 lebih kecil dari 0,05 $(0,011<0,05)$.

2. Hipotesis kedua diterima bahwa masyarakat yang tingkat pendidikan dasar dan menengah akan cenderung lebih mudah melakukan 
perceraian, sedangkan masyarakat yang tingkat pendidikan tinggi akan cenderung lebih mampu mengendalikan diri dari melakukan perceraian, karena variabel tidak dalam persamaan (variables not in the equation) skornya 5,738 dengan taraf signifikansi 0,017 lebih kecil dari $0,05(0,017<0,05)$.

3. Hipotesis ketiga diterima bahwa masyarakat yang memiliki latarbelakang jenis pekerjaan Non-ASN dan tingkat pendidikan dasar dan menengah akan cenderung lebih mudah melakukan perceraian, sedangkan masyarakat dengan latar-belakang jenis pekerjaan sebagai ASN dan tingkat pendidikan tinggi akan cenderung lebih mampu mengendalikan diri dari melakukan perceraian, karena variabel tidak dalam persamaan (variables not in the equation) skornya 10,861 dengan taraf signifikansi 0,004 lebih kecil dari $0,05(0,004<0,05)$.

\section{Referensi}

Ahmadi, Abu. Sosiologi Pendidikan, Surabaya: PT. Bina Ilmu, 1982

Arikunto, Suharsimi. Prosedur Penelitian: Suatu Pendekatan Praktek. Jakarta: Rineka Cipta, 1998

Azwar, Syaifuddin. Metodelogi Penelitian. Yogyakarta: Pustaka Pelajar, 1998

Burhan, Bungin. Metode Penelitian Kuantitatif, Jakarta: Prenada Media Group, 2005

Departemen Agama RI. Kompilasi Perundang-undangan Badan Peradilan Agama, Jakarta: Proyek Binbapera, 1980

Jusuf, Soewadji. Pengantar Metodologi Penelitian. Jakarta: Mitra Wacana Media, 2012

Kartono, Kartini. Tinjanan Holistik Mengenai Tujuan Pendidikan Nasional. Jakarta: PT. Anem Kosong Anem. 1997

Manan, Mohammad 'Azzam, "Kekerasan Dalam Rumah Tangga dalam Perspektif Sosiologis", Jurnal Legislasi Indonesia, Vol. 5 No. 3 (September 2008): 28-29.

Rokhmadi, Pengaruh Jenis Pekerjaan dan ... 
M, Arifin H. Ilmu Perbandingan Pendidikan, Jakarta: PT. Golden Terayon, 1987

Rofiq, Ahmad. Hukum Perdata Islam di Indonesia. Jakarta: PT. Rajawali Grafindo Persada. 2013

Saifuddin, Azwar. Reliabilitas dan Validitas. Yogyakarta: Pustaka Pelajar. 1997

Samsul, "Kasus perceraian tergolong tinggi, 70\% perceraian di Semarang diajukan perempuan," Semarang Pos, 19 Maret 2016, http://www.semarangpos.com/2016/01/28/kasus-perceraiantergolong-tinggi-70-perceraian-di-semarang-diajukan-perempuan685408. html.

Subana, M. dan Sudrajat. Dasar-Dasar Penelitian Ilmiah. Bandung: Pustaka Setia, 2001

Sugiyono. Metode Penelitian Kuantitatif Kualitatif dan $\mathrm{R}$ \& $D$. Bandung: Alfabeta, 2008

Sugiyono. Statistik Untuk Penelitian. Bandung: CV. Alfabeta, 2007

Tilaar, H.A.R. Perubahan Sosial Dan Pendidikan. Jakarta: PT. Grasindo Gramedia, 2002

Tyo, "Sebulan, 290 Janda baru di Semarang," Jawa Pos, 2 Maret 2016, http://www.radarsemarang.com/20160229/sebulan-290-jandabaru-di-semarang. html.

Undang-Undang Republik Indonesia Nomor 20 Tahun 2003 tentang Sistem Pendidikan Nasional.

Undang-Undang Republik Indonesia Nomor 5 Tahun 2004 tentang Aparatur Sipil Negara. 